\title{
Situating Sound: The Space and Time of the Dancehall Session ${ }^{1}$
}

\section{Julian Henriques}

Goldsmiths College, University of London

This research situates the multiple body of the Jamaica Dancehall "Crowd"(audience) in the intensities of the Sound System Session. This is a heterogeneous "acoustic space," and discontinuous ritual time, in which sexual expression and orientation, and racial attitudes, diverge from Jamaican norms. This essay proceeds to account for the propagation of this temporality and spatiality in terms of the electromechanical processes of the Sound System "Set" (equipment), that is control, power and transduction. It looks firstly at the Sound Engineers' sensorimotor engineering technique of compensation for monitoring and manipulating the auditory performance of the Set. Secondly it discusses the sociocultural procedures of the cutting and mixing of the music the Selector plays in the Session. The essay identifies these practices and procedures as the basic elements for many cultural, cybernetic, linguistic, or communication systems. In conclusion it is suggested that for the Engineers' and Selectors' instrumental techniques to be affective and effective they have to be brought into a proportional relationship with the Crowd's experience. The Crew do this through their embodied experience and expert evaluative judgement - which is considered as an example of analogical, rather than logical, rationality.

Every night of the week huge stacks of speakers and massively powerful amplifiers, known as the "Set" of the Sound System, are assembled on the streets of inner-city Kingston, Jamaica. ${ }^{1}$ These attract a substantial "Crowd," or "Massive," as the audience is called, who have, over fifty years established the "bashment," or "Dancehall Session," as a unique, shared, popular, open-air event. $^{2}$ In Jamaica the Sound System is an emblematic musical instrument, technological medium, and cultural apparatus. For many Sound Systems - such as the world famous Stone Love - are a livelihood, for many more, a way of life. ${ }^{3}$ The current genre Dancehall music is

\footnotetext{
${ }^{1}$ DRAFT to appear in Sonic Interventions, (eds) Marijke, Joy and Mieskowski, Sylvia, Amsterdam: Rodopi, forthcoming 2007.
} 
currently achieving international recognition, with Sean Paul, for example. Also the culture and technology of the Sound System has had a huge impact internationally on Hip Hop, Rap, Jungle, Drum \& Bass, Garage, and currently in the UK, Grime. Sounds Systems have also been a powerful influence on DJ performance techniques, recording studio practices, and the pleasures of listening in Raves, Clubs and Carnival. ${ }^{4}$

The auditory sense has particular value and importance across Jamaican society, especially in the downtown ghetto areas of Kingston where Dancehall music originates. Here, the open windows and corrugated zinc walls make sonic privacy impossible. The tropical heat downtown pushes people out onto the streets. This makes for a rich cacophony: children playing, car horns, motor bikes, radio, television, church services, sound systems, cocks crowing, not to mention the occasional gun shot. This distinctive shared open-air sonic "livity" (form of life) also forms is part of Jamaica's rich African musical heritage. ${ }^{5}$ The fecundity of traditional rhythms, like Kumina for example (see Ryman 1984), continues as a source for current Dancehall hits.

\section{The Phenomenon of the Crowd in a Dancehall Session}

Within the urban geography of Kingtston's Dancehall scene (see Stanely-Niaah, 2004a, 2004b), the Dancehall Session is situated as a living, embodied place, a habitat, or even a habitus, to use Bourdieu's (1992) term. ${ }^{6}$ Within this the Crowd is immersed in an intensive auditory field, described as "sonic dominance" (Henriques, 2003). This is generated by the massively powerful amplifiers in the "bowl" of sound between the stacks of speakers (see Figure 1), as described below. Approaching the upper limits of the auditory sensory threshold, sonic dominance is experienced as a subjective and deeply felt all-embracing sensory environment. The Crowd's sensorimotor experience of the Session in this way draws attention to its bodily, haptic, visceral and material experience of the medium of sound. This might be contrasted, for example, with privatised or individual listening, at more moderate levels, such as with a MP3 player, where the sound is, as it were, placed in the person, rather than the person in the sound. In the Session the sound touches the entire sensory surface of each of the listening bodies of the Crowd. But rather than accentuate the auditory sense alone, sonic dominance tends to merge sensory stimulation in a haptic multi-sensory flux. Intense auditory stimulation circulates, resonates and amplifies a sensory “ecology” of perception, to use Gibson's concept (Gibson, 1979, see Gallagher, 2005). 
about here:

Figure 1 Erecting the Merritone Sound System speaker stacks, Skateland, Kingston, July 2002.

The multi-sensory character of the Dancehall scene is evidenced by the value it places on style, fashion, attitude and dance moves, in addition to the music. All this is often literally enlarged in the Session, with live video cameras projecting images of members of the Crowd onto screens between the speaker stacks. The visual sense, the senses of touch, taste and temperature, and the kinetic sense of dance, share a combined intensity in the Dancehall Session that escapes ever being fully described, recorded, or reproduced. In the Sesseion, the Crowd experiences a unique specific 'thisness, ${ }^{7}$ that has to experienced as such - by 'being there.' As Merleau-Ponty (1962) put it: "The body is our medium for having a world." The Crowd is pleasurably compelled to allow the aural to monopolise their attention. Csordas describes this somatic mode of attention as “culturally elaborated ways of attending to and with one's own body in surroundings that include the embodied presence of others" (Csordas, 2002, p. 244).

about here:

Figure 2: Screen, dancers, camera (bottom right) at Chuchu Benz August Town Session, June 2004

There is also a particular relational or inter-subjective quality to the intensities when one is listening in this manner. This has been described with reference to the interlocutors of patient and analyst, by Roland Barthes. This kind of listening is

Not what is said or emitted, but who speaks, who emits such listening is supposed to develop in an inter-subjective space where 'I am listening' also means 'listen to me'... The injunction to listen is the total interpellation of one subject by another: it places above everything else the quasi-physical contact of these subjects (by 
voice and ear): it creates transference: 'listen to me' means touch me, know that I exist (emphasis in original Barthes [1976] 1985 pp. 245 - 251).

In the Session, of course it is the sound itself that is listened to - the "speaker" being the Set's loudspeaker. Such a state of listening can also be compared to what the psychoanalyst Didier Anzieu describes as the "sonic envelope" experienced by the unborn baby in the womb (Anzieu 1989). But for the Crowd this is a shared experience - as a multiple whole, assembly, ${ }^{8}$ or a collective social body, in which many are one, and one is many (see Canetti, 1960). What the Crowd may share with the foetus is a feeling of comforting warmth and security in a nurturing female space, as well as pleasure. The late Louise Fraser Bennett, co-founder of the Sound System Association of Jamaica, expressed this idea of the Crowd as a multiple whole, most eloquently. She described the Sound System's crucial role as:

...bringing together a set of people who shares the same habit and have the same way of life, the same movements, the same beliefs, the same heritage from that time to this... It brings a oneness, it brings together a people in one surrounding... it generates a vibes that brings one generation to the other generation, breaking down social barriers. There is nothing in this world that can contest that level of the Sound System that brings so much components together... ${ }^{9}$

This intensive multi-sensory, multi-subjective relationship the Crowd has with the event of the Session - through sound - helps to generate a particular kind of spatiality which is uneven, heterogeneous and contradictory. It is also full of feelings. This is evident, for example, in the confidence that the Dancehall Crowd has to assert its own rules and norms, as in a carnival parade, against those prevailing at other times and places. Dancehall culture positively asserts its own particular African inspired frame of reference to the female body and sexual display, against the specifically European conventions of modesty and propriety upheld in Jamaican middle class media, for example. This has an intensity that may urge one to apply a Marxist vocabulary, to describe the Crowd as being, a Crowd for itself, rather than merely in itself.

about here:

Figure 3: Dancehall Queen Stacey at Chuchu Benz August Town Session, June 2004 
For the Crowd the special kind of place and spatiality of the Session is one in which the norms of sexuality and sexual orientation can be inverted, in a manner consistent with Bakhtin's (1984) concept of the carnivalesque. Over recent years Dancehall artists such as Beenie Man and Sizzla have met press criticism and protest over their anti-gay lyrics, to the extent that their 2004 tour to The USA and UK was cancelled. ${ }^{10}$ The fact that this homophobia is part of the conservative and biblical inspired conventions of Jamaican society, does not, of course, offer any justification for such lyrical content. ${ }^{11}$ What is particularly interesting then, is how within the event of the Session itself, such homophobic attitudes are in fact suspended. At any other place or time such “batty man” behaviour would endanger the person's life. In fact, such male sexual display, elsewhere considered 'effeminate,' is quite central to the event of the Session, and Dancehall style itself. Examples of this include elaborate plated hairstyles, large fake diamond ear-studs, and the body-tight fitting trousers and T-shirts favoured by dancers such as the late Boggle. The dancers I filmed at a Firelinks Hot Mondays Session in 2004 repeated a stereotypically camp 'limp-wrist' gesture. Further at another Session I witnessed such 'effeminate' males taking part, completely whole-heartedly, in the chanting of the same 'gay-bashing' (homophobic) lyrics. ${ }^{12}$

The spatiality of the Dancehall Session is also a place where normal Jamaican racial attitudes and prejudices can be suspended. These commonly include not only chauvinism against islanders from the rest of the Caribbean, but also Afro-centric anti-white ideologies and religious beliefs such as Rastafarianism. Yet the Dancehall Session often appears, remarkably, to embrace racial diversity. This is indicated, for example, by that fact that the 2002 Dancehall Queen was the Japanese Junko 'Bashment' Kudo, ${ }^{13}$ and the winner of the 2005 World Cup Clash was the German Sound System Sentinel. ${ }^{14}$ Both these highly competitive positions were awarded by popular vote from the Dancehall floors, in Montego Bay and Brooklyn, respectively, by almost entirely Jamaican Crowds.

So how can these inversions and reversals of prevailing norms and attitudes be understood? The role of music in religious rites, to create trance and ecstatic (ex stasis, literally out of standing, or standing outside) states, has been described by ethnomusicologists (see for example Rouget, 1985). But it is the work of Marshall McLuhan and his collaborators in the 1950's, that is 
perhaps more useful for exploring the particular character of the space of sound. They made an explicit connection between sound and space, coining the term acoustic space.

The essential feature of sound... is not that it be located at a point, but that it be, that it fill auditory space... Auditory space has no point of favoured focus. It is a sphere without fixed boundaries with ourselves in the centre" (emphasis in original, Williams, 1955, p. 17).

This lack of a "favoured focus" characteristic of acoustic space - an absence of standardised structure, hierarchy or "normality" - resonates with the reversals and inversions found on the Dancehall scene. Acoustic spatiality is to be found in the particular, irregular and living place, or habitus of the Session. ${ }^{15}$ Describing what we would now call the pervasive and ubiquitous character of contemporary media, McLuhan identifies acoustic space as being "like the 'mind's ear' or acoustic imagination...It is both discontinuous and nonhomogenous. Its resonant and interpenetrating processes are simultaneously related with centres everywhere and boundaries nowhere" (McLuhan [1989] 2004, p. 71). By contrast, the topography of visual space is considered as rational - as distinct from embodied. ${ }^{16}$ This is linear, generic and organised round the single perspective of a point of view - without reversals or inversions:

Space perceived by the eyes when separated or abstracted from all other senses. As a construct of the mind, it is continuous, which is to say that it is infinite, divisible, extensible, and featureless (ibid).

And the particularly important qualities of acoustic space that make it useful in for describing the Dancehall Session, is its tendency to evoke emotions:

Auditory space has the capacity to elicit the gamut of emotions from us, from the marching song to opera. It can be filled with sound that has no 'object,' such as the eye demands. It need not be representational, but can speak, as it were, directly to emotion (Williams, 1955, p. 19).

The limitations of McLuhan's approach is, however, his tendency to essentialise and romanticise acoustic qualities and pre-literate oral traditions - rendering them strangely at odds with his theoretical ideas about historically specific technological mediations. ${ }^{17}$

As well as its particular spatiality, the Crowd's auditory engagement with the Session also generates a particular sense of time. Again, this is an uneven, embodied and intense kind of 
temporality, that appears to accommodate reversals and inversions. This moment-to-moment duration of the event of the Session necessarily involves movement, just as any sound, to be heard at all, requires a vibration of air molecules. Sound is always 'in time,' requiring continuous propagation - and therefore often features rhythm and repetition. Repeating time is cyclical, called kronos by the Ancient Greek philosophers, though this does not mean that kronos is monotonously the same. ${ }^{18}$ Indeed the opposite, as Lefebvre reminds us in his Rhythmanalysis of Mediterranean Cities: "Cyclical rhythms, each having a determined frequency or period, are also rhythms of new beginnings: of the 'returned' who is not opposed to the 'become'...Dawn is always new (emphasis added, Lefebvre and Régulier, 2004, p. 231). Indeed Kingston, Sessions are often named by the regular night of the week on which they are staged, as with the Firelinks' Hot Mondays, or Stone Love's Weddi Weddi Wednesday, for example. There is also a particular cycle to the duration of the event of the Session, which is mapped, from midnight to dawn the next morning, in the various styles, tempos, moods, and period of music tracks played by the Sound System's Selector, as discussed below. ${ }^{19}$

About here

Figure 4: Bashment poster naming MC, Artist, Sound System and Videoman

Further to its cyclical time, the Session can be described as generating the metaphysical temporality, eternal timelessness, or aion, typical of sacred events (see Deleuze, 1990. pp. 162-8, Turetzky, 1998, Bogue, 2003). ${ }^{20}$ The anthropologist of religion Marcia Eliade describes such temporality as the Eternal Return, the Golden Age, "'in those days' in illo tempore, ab origine" (Eliade, 1954: 4), ${ }^{21}$ or Fraser Bennett put it: "the same heritage from that time to this..." Eliade describes this as a special ancestral time, in which "all sacrifices are performed" as being:

At the same mythical instant of the beginning [where] though the paradox of rite, profane time and duration are suspended. And the same holds true for all repetitions, i.e., all imitations of archetypes; through such imitation, man is projected into the mythical epoch in which the archetypes were first revealed (Eliade [1949] 1954, p. 35).

This is not to suggest that the Session is a sacred place, though there are many connections between Dancehall and Church hall (see Beckford, 2006). The Session is a moment for pleasure, 
and the hope for the satisfaction of desires. ${ }^{22}$ Sound is used to make the Session a special liminal event, geared towards becomings, ritual transformations, rites of passage, and journeys over thresholds and across boundaries (see Turner, 1974). But further it is equally important that such wishes are only fulfilled temporarily and in the particular place of the Dancehall Session. This allows the Crowd to go about their "normal" lives at dawn, and motivates them to return to the Session on another night, for another journey. The Session allows the Crowd, already a multiple whole in the moment-to-moment duration of the event, to become situated as a spatial multiple different places at the same time, and situated as a temporal multiple - different times at the same place. $^{23}$

So, rather than having to explain such reversals and inversions of such heterogeneities, the question becomes: what stops these multiples from simply flying apart? Both kronos and aion, as senses of time, are synchronised with the more familiar linear, accumulative or progressive sense of time. For Sound System this is a relevant consideration, for example, in respect to the technological equipment of the Set being "up to date," or the Selector having "the latest" tunes to play. But in addition the auditory sense is critically important - particularly rhythm. Rhythm abounds in the Session: in the massively amplified stomach-churning bass-line, the syncopated beat of the music, the unique role of "riddim" tracks on the Dancehall scene (see Marshall and Manuel, 2006), the particular tracks played, and the procession of the night through the different tracks the Selector plays. ${ }^{24}$ And rhythm also holds together auditory and non-auditory material, as Turetzky reminds us:

Rhythms group heterogeneous material elements together. In music such elements include pitch, volume, timbre, and other aspects of sound, but rhythms may take up a great variety of other material... rhythms deploy parts of human bodies, their various motions. However rhythms, themselves, are always temporal intervals (that) become grouped together by distributing accented and unaccented moments... (Turetzky, 2002, pp. 124-5).

In this way rhythm can be said to situate temporal and spatial material together. This is another of the points Lefebvre makes when he says:

Concrete times have rhythms, or rather, are rhythms - and every rhythm implies a relation of a time with a space, a localised time, or if one wishes, a temporalised place. 
Rhythm is always linked to such and such a place, to its place, whether it be the heart, the fluttering of the eyelids, the movement of a street, or the tempo of a waltz (emphasis added, Lefebvre, 1996, p. 230).

These rhythms generate the heterogeneous and uneven spatiality and temporality of the Dancehall Session in which the "object" of the event and the Crowd are situated, and indeed from which they are constituted (see Fraser, 2005). ${ }^{25}$ Space and time do not exist as pre-given abstract dimensions. As Fraser, Kember and Lury put it:

The co-ordinates of space and time are not understood to be external to (relations between) entities. Change, that is, does not occur in time and space. Instead, time and space change according to the specificity of an event. The event makes the difference: not space and time. Importantly, motion and change are attributable to difference within the event (emphasis in original, Fraser et al, 2005, pp. 3-4).

The present investigation is concerned with the changing flux of relationships, processes, differences and becomings, rather than the fixed objects, structures, equivalences and being. So we now need to examine exactly how these rhythms are propagated in the performances, practices and procedures of the Crew and the Crowd, starting with the processes of the Set.

\section{Electromechanical Processes: Power and Control}

The Sound System Set is a multiple body, like the Crowd, but of technological component parts. As a phonographic apparatus the Set assembles amplifiers, pre-amps, FX boxes, equalisers, crossovers, mixers, mikes, cables, driver units, speaker bins, record and CD decks, mixing consoles and numerous other gadgets and devices. In contrast to the sensorimotor experience of the Session on the part of the Crowd, these operate in the electromagnetic and electromechanical milieux within its circuitry. To generate the rhythms and intensities required for sonic dominance, most Sound Systems today are capable of about 15,000 watts of music amplification.

The operation of these Sets can be understood in terms of a pair of processes: those for control

and information on the one hand; and those for power and energy, on the other. ${ }^{26}$ This distinction between control and power processes is critical. The cybernetics pioneer Gregory Bateson, in Mind and Nature, gives the example of the energy of the pressure of water in the pipe and the control mechanism of the tap to turn the flow partially on, fully on, or off. And even more 
important is the relationship between these processes: "the combining of the two systems (the machinery of decision and the source of energy)," Bateson tells us "makes the total relationship into one of partial mobility on each side" (Bateson, 1979, p. 102). ${ }^{27}$

And there is a further process entirely critical for the operation of the Set - if the Crowd are to hear anything. This is the relationship between amplified electromagnetic signals within the Set, and the auditory sound waves in the Session itself. This requires a process of transduction, which takes place in the transductive devices of the loud speakers, built up as columns of boxes round the dance area (see Figure 1). ${ }^{28}$ The MC's microphone reverses this transduction process, converting of audible sound waves into electromagnetic signals for the Set to amplify. The cartridge is another transducer, converting the stylus' vibrations from the mechanical indentations in the groove of the record, into an electronic signal. It is these power processes, and these of transduction, that the Engineers have to control - with their monitoring and manipulating practices, to which we now turn.

about here:

Figure 5: The Stone Love Set under repair, Skateland, July 2002

\section{Sensorimotor Practices: Monitoring and Manipulating}

The Sound Engineers who design, build and maintain the Sets have a particularly important part to play, given the crucial generative role for the spatiality and temporality of the Session attributed to auditory stimulation. The Engineers are responsible for the parameters, characteristics and qualities of the auditory output of the Set, as distinct from musical rhythms that it might be used to play. ${ }^{29}$ For this they use a technique of compensation to fine-tune the output of the Set. "What's the most important thing you learnt from [your teacher] John Jones?" I asked Denton Henry, Chief Repair Engineer for the Stone Love Sound System. ${ }^{30}$ He replied with one word: compensation, and went on to explain why:

He [John Jones] always tell me to compensate for this and compensate for that. If it don't sound right use the condenser and the resistor to compensate to get the sound that you [spoken loudly] want to hear... (You) either cut the bass, or to lift off the high frequency, 
cut the treble. With this now can juggle juggle. Compensation is a filter circuit [loudly]. You set it up for any frequency you want to hear. ${ }^{31}$

This technique requires both acts of monitoring, sensing, and listening for it to "sound right," as well as manipulating, that is adjusting to "cut the bass, or to lift off the high frequency... juggle juggle." Describing compensation in this way identifies it as a sensorimotor technique - a practice that is both haptic, concerning sensory impressions and feelings, and kinetic, concerning bodily expressions and movement.

All techniques require appropriate instruments or devices. With compensating these are the "gates," crossovers or filters to restrict electromagnetic frequencies that may be manipulated by means of variable controls knobs or faders. "Back in the day," Denton Henry told me, tuning the Set required digital dexterity - de-soldering one component, and re-soldering another in its place, ${ }^{32}$ as each frequency had its own compensation circuit:

... At that time when you tune it was fixed [loudly]. You couldn't go out there and use the equaliser and vary it. No knob, couldn't adjust it. Afterward now I put on rotary switch... ${ }^{33}$

Every component of the Set can be subject to compensation, from the needle on the record, to the positioning of the speaker stacks on the Dancehall floor. The Engineer listens, and then adjusts, monitors and then manipulates the value of one of the components. He monitors, he compensates, he listens again, and makes another adjustment, and so on. With the auditory feedback of what he hears, as part of goal-orientated cybernetic system as it were, gradually the Engineer closes the gap between what he is hearing and that for which he is listening. ${ }^{34}$ Then the tuning is complete.

So what is the sonic goal the Engineers are trying to reach? "Clarity," "bounce," and "sweetness" are some of the key terms I heard used to describe the sonic qualities for which the Engineer aimed their fine-tuning. But most import of all was "balance." Denton Henry told me "I put balance between the bass, the mid and the top" (ibid). Further, Horace McNeal explained how: "I listen for everything I know in the tune supposed to come out of my box. If I don't hear what I know in it I not stop tuning, turning, push down this, carry up this, until I hear what I want.",35 
Thus the Engineers fine-tune their Sets to produce the very best sound they are capable of producing, just as a musician tunes their instrument. ${ }^{36}$

But how does the Engineer know when the tuning is complete? How does he know the desired sound is "supposed" to be? Compensating clearly requires qualitative evaluations and personal subjective judgements. This means that the technique cannot be considered as a sensorimotor practice alone, but also has to be included in the sociocultural milieu. Sound Engineers have to professionalise their listening, develop specialist skills and expertise (see Levin, 1989), to become connoisseurs of sound, so to speak. They have to listen with understanding, sensitivity, knowledge, sympathy, appreciation and discrimination to the fine grain details and nuances of sound. Such listening, it was found, has been developed through an apprenticeship system between the generations of Jamaican Sound System Engineers. ${ }^{37}$ This achieves the aural sophistication critical for the way they engineer, which is almost entirely "by ear," rather than with reference to technical manuals, I was told by Horace McNeal. And as his teacher Denton Henry told me, it was his own teacher, John Jones, who "shape[d] my whole listening." listening skills are evidently passed from generation to generation of Engineer.

This makes the critical distinction between hearing and listening in terms of evaluation. As Jonathan Sterne emphasises in The Audible Past: "Listening is a directed, learned activity: it is a definite cultural practice. Listening requires hearing but is not simply reducible to hearing" (emphasis added, Sterne, 2003, p. 19). Barthes put this important point as follows:

Hearing is a physiological phenomenon; listening is a psychological act. It is possible to describe the physical conditions of hearing (its mechanisms) by recourse to the physiology of the ear; but listening cannot be defined only by its object or, one might say its goal (emphasis in original, Barthes, 1985, pp. 245).

Further than the object of hearing, it is of course the listening subject, that is required to define the practice of listening. This inter-subjective character of the Engineers' listening, like that of the Crowd, does not make it any the less a personal, subjective and embodied issue. This point was by DJ Squeeze, who told me, while tuning up his Set, what he was listening for was "my harmony with the sound.,39 


\section{Sociocultural Procedures: Cutting and Mixing}

From the Crowd's point of listening in the Session, it is the Selector's music, rather than the Engineer or the Set itself that absorbs their attention. The Selector is so-named as the Crew Member whose job consists of choosing the vinyl records from the record box, and placing them on the turntable, while the MC (Master of Ceremonies) "chats" on the microphone. ${ }^{40}$ In the sociocultural milieu of the Dancehall Session, the procedure brought into play here is cutting between different pieces of music. Mixing is the other procedure by which the Selector accomplishes a smooth transition from one record to the next, through the entire musical flow of the night. ${ }^{41}$ This is achieved by means of the device of the faders on the mixing desk. This pair of procedures resonates both with the processes of the Set, and those of sonic engineering. Furthermore, the music producer in the studio is also entirely familiar with the cutting procedure, as he or she selects one particular music multi-track to adjust in his or her mixing.

One important feature of the relationship between the cutting and mixing pair is they are practiced together in the same spatial and temporal event: as selecting and mixing, cutting and pasting, sampling and splicing, for instance. The second feature of cutting and mixing is that they are always situated at the same event in time. There is only ever a re-mix, never a pristine un-re-mixed mix, as it were, for the Engineer, Selector or Record Producer to listen to. (It may be the Crowd's wish to deny the material fact of this re-mixing, that is their own fleshly corporeality, that motivates their journey for the ab origine, the perfect time before time.) Though inseparable in practise, cutting and mixing can be analytically isolated. As an abstract process, cutting involves separating, dividing things up, sorting, fragmenting, dis-aggregating, parting, tearing, splitting the whole, differentiating, creating boundaries, making a choice and analysing. Mixing by contrast is a process of combining, amalgamating, aggregating, bringing things together and synthesising. It tends to be much easier to do than undo, like mixing sugar in a coffee for example, or recording two instruments onto a single audio track. Mixing, as a power process, generates intensities, feelings and energies.

Two features of cutting and mixing are remarkable. One is their ubiquity. The cut and mix, for Hebdige, means identifying the present era of popular music: "Cut ' $\mathrm{n}$ ' mix is the music and the style of the 1980's just as rock 'n' roll and rhythm ' $n$ ' blues formed the bedrock for the musics 
and styles that have made such an impact on our culture since the 1950's" (Hebdige, 1987, p. 10). Cox and Warner, discussing DJ culture of the 1990's, identify these same two processes: DJ Culture has worked with two essential concepts: the cut and the mix. To record is to cut, to separate the sonic signifier (the 'sample') from the original context or meaning that it might be free to function otherwise. To mix is to reinscribe, to place the floating sample into a new chain of signification (emphasis in original, Cox and Warner, 2005, p. $330)$.

The second remarkable characteristic of cutting and mixing is how they play a part in all manner of different communication systems. The cutting and mixing pair can be described as elemental linguistic procedures, as they are by Roman Jakobson, in Two Aspects of Language and Two Types of Aphasic Disturbances [1956] (1971). He states "speech implies a selection of certain linguistic entities and their combination into linguistic units" (emphasis added, Jakobson, 1971, p. 58). Cutting takes place in the paradigmatic or metaphoric relationship between units of language system (see also Gates, 1988). Mixing is the syntagmatic or metonymic combination between linguistic units. As with every particular tuning of a Set, every particular linguistic utterance is made from a mixing or combination of both paradigmatic selection and syntagmatic combination. In System and Structure Anthony Wilden makes this point as follows:

Metaphor and metonymy are not linguistic processes: they are communicational processes. Selection from the code and combination in the message must and do occur in any communications system whatsoever, whether in the genetic code of the DNA molecule, or in the organism, or in the life processes of bacteria, or in a social system... All communication in systems of communication - ecosystems - involves an axis of selection and an axis of combination (emphasis added, Wilden, 1972, pp. 351-2). Identifying cutting and mixing as elemental procedures - in both sound engineering and language use - suggests that both non-representational communication systems, like the Sound System, and representational ones, such as a language system, ${ }^{42}$ can be understood as operating in a similar manner. ${ }^{43}$

about here:

Figure 6: Axes of communication for Engineer, Set and Session 


\section{Situating sound: ratio and kairos}

But the operating characteristics of communication systems, whether linguistic or electromechanical, are not sufficient to account for how they are used, or what for. While compositional rules may prescribe what counts as correct selection and combination for linguistic - and indeed musical - performance, it is the Engineers' and Selectors' embodied personal judgement that has to be at the heart of any understanding their performance in the Dancehall Session. In each case, it is suggested here, qualitative judgments are being made on the basis of the proportional relationship between subjectivities of experience on the one hand, and the objectivities of the situation on the other. This is a relationship of the continuous analogue variation of sensation, rather than the distinct diacritical differences of a communication system. It concerns the material as distinct from the ethereal aspect of sound (see Henriques 2003). Auditory propagation needs to be an energetic power process before it can be controlled for the purposes of communication. The linguistic equivalent of such material processes is the prosody of vocal production of an utterance - the aspect of language that formalist approaches find easiest to overlook. This is what gives every utterance and every speaker, and every instrumentalist, their unique individual tone. Indeed the Engineers, and some of the Crowd, consider a Sound System Set, with its particular components and power and control settings, as having its own character, or distinctive voice. Such particular qualities of sound cannot be reduced to the technologies their production requires, any more than the elements of a language system are sufficient to account for what it is used to say, or the mechanisms of hearing could gave an adequate account of listening.

The Engineers' recognition of the correct sonic quality of "balance," for example, can be identified as an example of a proportional relationship, or ratio (see Critchlow, 1994). Other examples of such spatial relationships include the Golden Section in architecture, or the musical

octave in sound, that is an intuitive recognition of balance or harmony (see Bass, c. 2000). ${ }^{44}$ Bateson's cybernetics also provides a grounding for this emphasis on the importance of relationships, both from its origins in the study of biological organisms, that is fleshly bodies, and from his definition of information as "news of difference" (1979, p. 69) and "differences that 
make a difference" (p. 99). ${ }^{45}$ Information is thus not an object, or a statistical probability, isolated in the material physical world of quantities, but a human evaluative relationship. As Bateson explains: "difference, being of the nature of relationship, is not located in time or space" (additional emphasis added, Bateson, 1979, p. 98). Nevertheless, such relationships have to be tangible by means of the medium through which they are expressed - sound in the case of the Sound System.

The Selector's skilled judgment as to exactly which tune to play when, provides another example of his or her embodied, intuitive and subjective evaluation of the proportional relationship between the subjective feelings of the Crowd and the objective fact, so to speak, of what they have in their record box. This is a temporal proportional relationship that will always escape rules. The key quality to any such live performance is the performer's sense of timing, being "in time," on the beat, or "ridding the rhythm" as would be said. This is timeliness or the opportune moment, or kairos ( $\chi \alpha \iota \rho o ́ \varsigma)$ at the heart of every particular improvised performance, or interpretation (see Onians, 1951 pp. 343-51, White, 1987). The term kairos describes the entirety of the Session, as rhetorical scene, in the moment-to-moment proportional relationship between aion, or timelessness, and kronos, or cyclical time. Such embodied evaluations make the literally vital link between the subjectivies and objectivities of the Session. It is the Crew and Crowd's embodied know-how that forges a chiasm, to use Merleau-Ponty's term, holding the elements of different practices together. This is a proportional relationship between electromechanical, sensorimotor and sociocultural milieux: for the Crew between ear and hand, monitoring and manipulating, cutting and mixing. For the Crowd this is between body and mind, haptics and kinetics, music and dance as their experience of the rhythms and intensities of sonic dominance, resonating with their multiple bodies.

The spatiality and temporality of such proportional relationships - as ratio or kairos - can be identified as an example of analogical rationality (see Critchlow, 1994). Analogy and metaphorical thinking (see Lakoff and Johnson, 1980, Johnson, 1987) requires such relational qualities, as is recognised to some extend in the selecting or metaphorical axis of communication. This may be distinguished from what is more familiar in theory, that is the logical rationality of representation, quantities, discrete differences and calculation. This research 
has concerned itself with situating sound in practice: the Crowd's embodiment in the heterogeneous time and space of the Session, the Crew's procedures along the axes of communication - as well as their proportional evaluations. One of its aims has been to investigate how both analogia and logic are equally important aspects of rationality, or logos.

j.henriques@gold.ac.uk

\section{References}

Anzieu, Didier. The Skin Ego: A Psychoanalytic Approach to the Self. New Haven: Yale University Press, 1989.

Ashby, W. R. An Introduction to Cybernetics. London: Methuen, [1956] 1964.

Bakare-Yusuf, Bibi The Sea of Memory: Embodiment and Agency in the Black Diaspora. Ph.D. Diss., Faculty of Social Sciences, University of Warwick, 2001.

Bakhtin, M. M. Rabelais and his World. (Trans. Iswolsky, H.). Bloomington: Indiana University Press, 1984.

Barthes, Roland. "Listening." (Trans. Howard, R.) The Responsibilities of Forms: Critical Essays on Music Art and Representation. Oxford: Basil Blackwell, [1976] 1985, 245-260.

Bass, Steven. "Listening for the Harmony of Apollo, Part I: Unity, Geometry and Beauty in Architecture," American Arts Quarterly, 18. 2. (c. 2000). Retrieved, $24^{\text {th }}$ June, 2006 from http://www.nccsc.net/Arch/Arch_Essays/spr_01_bas/spr_01_bas.html

Bateson, Gregory. Steps to an Ecology of Mind. St Albans: Paladin, 1972.

Bateson, Gregory. Mind and Nature: A Necessary Unity. London: Wildwood House, 1979.

Beckford, R. Jesus Dub: Audio, Pentecostalism and Social Change. London: Routledge, 2006. 2003.

Bogue, Ronald. Deleuze on Music, Painting, and the Arts, London: Routledge,

Bourdieu, Pierre. Outline of a Theory of Practice. Cambridge: Cambridge University Press, 1977.

Bourdieu, Pierre. The Logic of Practice. London: Polity Press, 1992. 
Bradley, Lloyd. Bass Culture: When Reggae Was King. London: Viking, 2000.

Campbell, A.C. "Reggae Sound Systems." Ed. C. Potash. Reggae, Rasta, Revolution - Jamaican Music from Ska to Dub. New York: Schirmer Books, 1997. 197211.

Canetti, Elias. Crowds and Power. Harmondsworth: Penguin, [1960] 1973.

Capek, Milic (1971) Bergson and Modern Physics: a reinterpretation and reevaluation, Boston Studies in the Philosophy of Science, volume 7, Dordrecht: D. Reidel Publishing Company

Chude-Sokei, L. '’Dr. Satan's Echo Chamber:' Reggae, Technology and the Diaspora Process," Bob Marley Lecture, Institute of Caribbean Studies, Reggae Studies Unit, University of the West Indies, Mona. 1997.

Clements, F. E. Plant Succession: An Analysis of the Development of Vegetation. Washington D.C.: Carnegie Institution of Washington, 1916.

Cooper, Carolyn. Noises in the Blood: Orality, gender and the 'Vulgar' Body of Jamaican Popular Culture. London: Macmillan, 1993.

Cooper, Carolyn. Sound Clash: Jamaican Dancehall Culture at Large. New York: Palgrave, 2004.

Cox, C. and Warner, D. (eds.). Audio Culture: Readings in Modern Music. London: Continuum. 2005.

Critchlow, K. "The Platonic Tradition on the Nature of Proportion. Ed. C. Bamford, Rediscovering Sacred Science Edinburgh: Floris Books. 1994. 133-168.

Csordas, T. J. Body/ Meaning/ Healing. New York: Palgrave, 2002.

Classen, C. "McLuhan in the Rainforest." The Empire of the Senses: The Sensual Culture Reader. Ed. D. Howes, Oxford: Berg, 2005. 147- 163.

Deleuze, Gilles. Difference and Repetition. (Trans. P. Patton). London: Continuum, [1968] 1997.

Deleuze, Gilles. The Logic of Sense. (Trans. M. Lester). London: Athlone, 1990.

Eshun, Kodwo. More Brilliant Than the Sun: Adventures in Sonic Fiction. London: Quartet, 1998. 
Eliade, Marcia. The Myth of the Eternal Return. (Trans. W. R. Trask). New York: Pantheon Books, [1949] 1954.

Foucault, Michel. "Of Other Spaces.” Diacritics 16, Spring, (1986): 22-27. Retrieved on $15^{\text {th }}$ June, 2006, from http://foucault.info/documents/heteroTopia/foucault.heteroTopia.en.html

Fraser, Miriam. "Making Music Mater." Theory, Culture \& Society 22.1. (2005): XXX

Fraser, M. Kember, S. and Lury, C. (2005). Inventive Life: Approaches to the New Vitalism, Theory, Culture \& Society, 2005, Vol. 22 (1).

Gates, H. L. (1988). The Signifying Monkey: A Theory of African-American Literary Criticism. Oxford: Oxford University Press.

Gilroy, P. (1987). There Ain't No Black in the Union Jack. London: Hutchinson.

Gibson, J. J. (1979). The Ecological Approach to Visual Perception. London: Houghton Mifflin.

Hansen, Mark (2001) Internal Resonance, or Three Steps Towards a Non-Viral Becoming, Culture Machine, retrieved $4^{\text {th }}$ August 2006 from http://culturemachine.tees.ac.uk/Cmach/Backissues/j003/Articles/hansen.html

Hayles, N. K. (1999). How We Became Post Human: Virtual Bodies in Cybernetics, Literature and Informatics. Chicago: University of Chicago Press.

Hebdige, D. (1979). Subculture: the Meaning of Style. London: Methuen.

Hebdige, D. (1987). Cut 'n' Mix: Culture, Identity and Caribbean Music. London: Comedia.

Henriques, F. (1953). Family and Colour in Jamaica. London: Eyre and Spottiswoode.

Henriques, J. (2003). Sonic Dominance and the Reggae Sound System. In Bull, M. and Back, L. Eds. Auditory Culture. (pp. 451-480). Oxford: Berg.

Heylighen, F (1993). Cybernetics, in F. Heylighen, C. Joslyn and V. Turchin (editors): Principia Cybernetica Web (Principia Cybernetica, Brussels). Retrieved June $12^{\text {th }}, 2006$ from http://pespmc1.vub.ac.be/CYBERN.html

Hope, D. P. (2006). Inna di Dancehall: Popular Culture and the Politics of Identity in Jamaica. Kingston: UWI Press. 
Ivins, W.M. [1938] (1975). On the Rationalization of Sight. New York: Da Capo

Jakobson, R. [1956] (1971). Two Aspects of Language and Two Aspects of Aphasic Disturbances, Fundamentals of Language. The Hague: Mouton.

Johnson, M. (1987). The Body in the Mind: The Bodily Basis of Meaning, Imagination, and Reason. Chicago: University of Chicago Press.

Katz, D. (2000). People Funny Boy: the Genius of Lee 'Scratch' Perry. Edinburgh: Payback Press.

Katz, D. (2003). Solid Foundation: An Oral History of Reggae. London: Bloomsbury.

Knabb, K. (1981). (Ed. and Trans.). Situationist International: Anthology. Berkeley: Bureau of Public Secrets.

Lakoff, G. and Johnson, M. (1980). Metaphors We Live By. Chicago: University of Chicago Press.

Latour, B. (1986). Visualization and Cognition: Thinking with Eyes and Hands, Knowledge and Society: Studies in the Sociology of Culture Past and Present, Vol. 6, pp. $1-40$.

Lefebvre, H. and Régulier, C. [1985] Le Project Rhythmanalytique, in Communications, 41. Also in Lefebvre, H. (1996) Writing on Cities. Oxford: Blackwell.

Levin, D. M. (1989). The Listening Self: Personal Growth, Social Change and the Closure of Metaphysics. London: Routledge.

Lewin, O. (2000). Rock It Come Over: The Folk Music of Jamaica. Kingston: University of the West Indies Press.

Mackenzie, A. (2002). Transduction: bodies and machines at speed. London: Continuum.

Marshall, W. and Manuel, P. (2006). The Riddim Method: Aesthetics, Practice and Ownership in Jamaican Dancehall, Popular Music, Vol. 25, 3.

Mazzio, C. (2005). The Senses Divided: Organs, Objects and Media in Early Modern England, The Empire of the Senses: The Sensual Culture Reader, Howes, David (ed.). Oxford: Berg

McLuhan, M. [1989] (2004). Visual and Acoustic Space Audio Culture: Readings in Modern Music. (eds.).Cox, C. and Warner, D. London: Continuum. 
Merleau-Ponty, M (1962) The Phenomenology of Perception. London: Routledge and Kegan Paul.

Onians, R. B. (1951) The Origins of European Thought. Cambridge: Cambridge University Press. Routledge.

Romanyshyn, R. D. (1989). Technology as Symptom and Dream, London:

Rouget, G. (1985). Music and Trance: A Theory of Relations between Music and Possession. Chicago: University of Chicago Press.

Roughgarden, J., May R. M. and Levin, S. A., (Eds.). (1989). Perspectives in Ecological Theory. Princeton: Princeton University Press.

Ryman, C. (1984) Kumina - Stability and Change, The African Caribbean Institute of Jamaica Research Review, 1, 81-128.

Simondon, G.(1992) The Genesis of the Individual, in Crary, Jonathan and Kwinter, Sanford, eds (1992) Incorporations, Zone 6, New York: Zone.

Spencer-Brown, G [1969] (1973). Laws of Form. New York: E.P. Dutton.

Stanley-Niaah, S. (2004a). Kingston's Dancehall: A Story of Space and Celebration, Space and Culture, Vol. 7, No. 1, 102-118.

Stanley-Niaah, S. (2004b). Making space: Kingston's Dancehall culture and its philosophy of 'boundarylessness' in African Identities, Volume 2, Number 2 / November 2004,117 - 132

Sterne, J. (2003). The Audible Past: Cultural Origins of Sound Reproduction. London: Duke University Press.

Stolzoff, N.C. (2000). Wake the Town and Tell the People. Durham: Duke University Press.

Tarnas, R.(1991). The Passion of the Western Mind. New York: Random House.

Turetzky, P. (1998). Time, London: Routledge.

Turetzky, P. (2002). Rhythm: Assemblage and Event, Strategies, Vol. 15, No, 1, 121-138.

Turner, V. (1974). Dramas, Fields and Metaphors. Ithaca: Cornell University Press. 
Salewicz, C., Boot, A., Abrams, H. N. (2001). Reggae Explosion: The Story of Jamaican Music, London Virgin Publishing.

Snead, J. A. (1981). On Repetition in Black Culture, Black American Literary Forum, 15, 4, pp. 146-154.

Varela, F. J. (1999). Ethical Know-How: Action, Wisdom, and Cognition, Stanford: Stanford University Press.

White, E. C. (1987). Kaironomia: on the will to invent. Ithaca: Cornell University Press.

White, G. (1984). The Development of Jamaican Popular Music pt. 2, The African Caribbean Institute of Jamaica Research Review, 1, 47-80.

Wiener, N. (1948). Cybernetics or Control and Communication in the Animal and the Machine. Cambridge: MIT Press.

Wiener, N. (1950). The Human Use of Human Beings. New York: Anchor

Wilden, A. (1972). System and Structure: Essays in Communication and Exchange. London: Tavistock.

Williams, D.C. (1955). Acoustic Space, Explorations, Feb., pp. 15-20.

Weheliye, A. G. (2005). Phonographies: Grooves in Sonic Afro-Modernity. Durham: Duke University Press.

Zabel, G. (1990). Ernst Bloch and the Utopian Dimension in Music, The Musical Times, Vol. 131, No. 1764, Feb.

Figure 1: Erecting the Merritone Sound System speaker stacks, Skateland, Kingston, July 2002

Figure 2: Screen, dancers and camera (bottom right) at Chuchu Benz August Town Session, June 2004

Figure 3: Dancehall Queen Stacey at Chuchu Benz August Town Session, June 2004

Figure 4: Bashment poster naming MC, Artist, Sound System and Videoman

Figure 5: Stone Love Set under repair, Skateland, Kingston, July 2002

(NB the order of Figs 4 and 5 has been reversed from their naming as Jpeg files) 
Figure 6: Axes of Communication for Set, Engineer and Session

\begin{tabular}{|l|l|l|}
\hline \multicolumn{1}{|c|}{ System } & \multicolumn{2}{c|}{ Communication Axis } \\
\hline$\underline{\text { SET }}$ & METAPHOR & METONYM \\
electromechanical & $\begin{array}{l}\text { control } \\
\text { transducer }\end{array}$ & $\begin{array}{l}\text { power } \\
\text { amplifier }\end{array}$ \\
\hline$\underline{\text { ENGINEER }}$ & $\begin{array}{l}\text { monitoring } \\
\text { ear }\end{array}$ & $\begin{array}{l}\text { manipulating } \\
\text { hand }\end{array}$ \\
\hline$\underline{\text { SESSOrimotor }}$ & $\begin{array}{l}\text { cutting } \\
\text { sociocultural }\end{array}$ & $\begin{array}{l}\text { mixing } \\
\text { intensities }\end{array}$ \\
\hline Language & paradigmatic & syntagmatic \\
\hline
\end{tabular}

1 Earlier versions of this essay were presented at the ASCA Conference Sonic Interventions, Amsterdam, 29-31 April, 2005.

2 This paper is part of a larger research project on the music, culture and technology of the Reggae Sound System in downtown Kingston, Jamaica. The research material on which it is based comes from my observation of Sessions and in depth interviews with Owners, Engineers, Selectors, MCs and Crowd (audience) and Followers (dedicated fans) mainly of the Stone Love Sound System, as well as observation an filming the Dancehall scene up to 2004.

3 Stone Love is the particular Sound System that I have researched most closely. See http://www.imexpages.com/stonelove/company profile.htm retrieved 5th July 2005. See also Cooper (1993, 2004) Katz (2000), Chude-Sokei (1997), Bradley (2000), Stolzoff (2002), Salewicz and Boot (2001) Bakare-Yusuf (2001), Stanley-Niaah (2004a, 2004b) and Hope (2006). For the British Sound System culture see the somewhat less recent Gilroy (1987: Ch 5) and Hebdige (1979, 1987).

4 Those friends and colleagues I would particularly like to thank for their helpful comments, encouragement and inspiration include Couze Venn, Steve Goodman, Jeremy Weate, BakareYusuf, Bibi and David Morley. Also I would like to thank my interviewees for sharing their knowledge and insight, particularly the late Ms Louise Fraser Bennett, Winston "Weepow' Powell, Horace McNeal, DJ Squeeze, Denton Henry and Hedley Jones.

5 As researched by Cheryl Ryman (1984), Olive Lewin (2000) Garth White (1984) and Fernando Henriques (1953).

6 The aspect of situating resonates with Guy Dubord's and others inspiration for the 1960's French "Situationists" political movement, and with the latter "happenings," as unique live, one-off events (see Knabb, 1981).

7 The idea of thisness is attributed to the Medieval philosopher John Duns Scotus who contrasted the haecceity of a particular qualities of an object with their quidtitity, or "whatness." 8 The term assembly resonates with the character of the Dancehall Crowd, as Mazzio notes in the entirely different context, of the Renaissance experience of theatre. "A word used as often as 'spectator' and 'audience' to describe playgoers in the Renaissance was the 'assembly.' A word worth reintegrating in the sensory dimensions of theatrical experience, because it implied not only a coming together of persons, but a physical touching of bodies in space" (Mazzio 2005: 87).

9 My interview with Louise Fraser Bennett, Press Secretary for the Sound System Association of Jamaica, on 26th July 2002, Kingston. 
10 See BBC reports and others at http://www.freemuse.org/sw7765.asp, accessed 12 January 2006.

11 See Gary Younge's article, Troubled Island, The Guardian $27^{\text {th }}$ April 2006, retrieved 14th June 2006

from http://www.guardian.co.uk/Columnists/Column/0,1762156,00.html

12 This was at one of the longest established and most mixed, in terms of age, Sessions 'kept' at Rae Town in downtown Kingston on Sunday nights.

13 http://www.bashmentvibes.com/pro junko.htm, accessed 25th February 2006

14 For a report of the event, see http://www.claat.com/article/articleview/1032/1/25/ retrieved 12th Feb 2006.

15 Romanyshyn (1989) distinguishes between the Medieval city as an example of higgledy-piggledy

auditory spatial layout, as distinct from the wide open perspectives of Parisian boulevards as an example of

visual space.

16 This idea of the rationalisation of vision was first explored by Ivins [1938] and more recently Latour (1986).

17 For a useful critique of McLuhan in this respect see Classen (2005). Further Sterne (2002; 15-19) provides a pointed analysis of the shortcomings of what he terms the 'audio-visual litany' which, although targeting McLuhan's contemporary Walter Ong, is equally applicable to McLuhan's position.

18 For a seminal discussion of Hegel and the Western philosophical tradition's abhorrence of the idea of repetition see Snead (1981).

19 The Sound System Crew has highly specialised, principally Selector, who selects the records, DJ or MC who talks on the mic, and the FX responsible for sound effects (see Campbell, 1997).

20 This suggestion clearly requires much more detailed and substantial investigation than the space here allows, and indeed is part of my ongoing research.

21 Deleuze (1997, p 159, note 12) refers to Eliade in his discussion of his concept of Repetition in Itself.

22 Ernst Bloch would describe this as a utopia (see Zabel, 1990) and Foucault (1986) a heterotopia.

23 In a Structuralist theoretical framework this would be considered as 'diasporic' and 'syncretic'

respectively.

24 Rhythm as both as a patterning of flows, and as a particular feature of Dancehall music, are central to my research concerns.

25 This could theorised in terms of metastabilities, that is the persistence of non-equilibrium over time (for Simondon's use of this see Hansen, 2001), or with the concept of the climax of an ecologically stable and mature communities, such as desserts or Tropical rain forests (see Clements, 1916, Roughgarden, 1989).

26 This distinction also parallels mine between ethereal and material aspects of sound (Henriques 2003).

27 It should be noted also that Bateson's discussion of this point is in the context of a discussion of how even control processes require what he terms 'collateral' energy.

28 The process of transduction as a relationship between different milieux has been important for Simondon, see Simondon (1992) and MacKenzie (2002).

29 Women play a crucial role on the Dancehall scene in numerous important respects, but none, as far as I have found, have become Sound System Engineers. I therefore refer to Engineers with the male pronoun. 30 During this research I tended to make the assumption that there was a homology between the Sound Engineers' understanding or know-how of their own practices and my own theoretically informed conception know-what about their practice (for a discussion of this distinction see Varela, 1999). Of course this need not be the case, but it is important that the status or veracity of what they say is questioned. The Sound Engineers might have all kinds of motives for thinking or talking about what they do the way they do.

31 My interview with Mr Denton Henry, Kingston, 24th June 2004.

32 Currently the graphic equalisers and variable crossovers with their own visual displays offer the Engineer an even finer degree of control. Also, as DJ Squeeze with his Skyy (sic) Sound System showed me on his mobile Sound System truck, Thunder, different mixes can be digitally stored ready for use at different venues.

33 My interview with Mr Denton Henry, Kingston, 24th June 2004.

34 A cybernetic system may be homeostatic, maintaining a system's stability across varying conditions, as with the thermostat maintaining a consistent room temperature, or a steam engine governor maintaining a constant speed across variations of load (see Bateson, 1979, pp. 103-109). This discipline was defined by Norbert Wiener as "the science of control and communication, in the animal and the machine" (Ashby 1956: 1, Wiener 1948, see also Heylighen 1993) and developed with respect to social theory by Gregory Bateson (1972 and 1979). 
35 My interview with DJ Squeeze, a.k.a. Mr Glenworth Samuels, Kingston, 22nd June 2004. Unlike of the other interviewees DJ Squeeze is has no official connection with Stone Love. Since the mid 1990's he has owned and operated his mobile sound truck Skyy (sic) Sound System and since 2002 owner and CEO of Magajamz Radio Station. 36 This suggests that the mediating processes of fine-tuning, are as important for phonographic reproduction (see Weheliye, 2005), as they are for 'original' sonic production. See also Eshun (1989: 188-9) for a critique of Benjamin's famous concept of the 'aura.'

37 As is detailed in my ongoing $\mathrm{PhD}$ research.

38 My interview with Mr Denton Henry, Kingston, 24th June 2004.

39 My interview with DJ Squeeze, a.k.a. Mr Glenworth Samuels, Kingston, 22nd June 2004.

40 In other popular music genres, besides Reggae and Dancehall, the roles of the Selector and the MC are both performed by the DJ.

41 As with the variable control knob facilitating the compensation that could previously done by resoldering components (mentioned above), both the fader and indeed the second turntable on the Set were historically specific innovations, that I have detailed elsewhere in my research.

42 Though it can be noted that for Structural linguistics this matter of representation is indefinitely differed, in so far as the relationship between signifier and signified is considered to be arbitrary, and signification is considered a property of the signifying system alone.

43 These two processes are certainly central to Freudian dream theory as condensation and displacement, that according to Wilden, can be traced back to Locke's theory of the association of ideas by contiguity; and association by similarity (Wilden, 1972, p. 37).

44 Proportional relationships were certainly recognised in the Ancient Greek philosophy of Pythagoras and Plato for whom the Beautiful as well as the Good and the True were equally valuable for philosophical enquiry, see Tarnas (1991).

45 This is taken as favouring MacKay, as against the widely accepted Shannon-Weaver Information Theory, see Hayles (1999). 